\title{
Seasonal changes in diets of seabirds in the North Water Polynya: a multiple-indicator approach
}

\author{
Nina J. Karnovsky ${ }^{1, *}$, Keith A. Hobson ${ }^{2}$, Sara Iverson ${ }^{3}$, George L. Hunt Jr. ${ }^{4,5}$ \\ ${ }^{1}$ Pomona College, Department of Biology, 175 W. 6th St., Claremont, California 91711, USA \\ ${ }^{2}$ Environment Canada, 11 Innovation Blvd., Saskatoon, Saskatchewan S7N 3H5, Canada \\ ${ }^{3}$ Dalhousie University, Department of Biology, 1355 Oxford St., Halifax, Nova Scotia B3H 4J1, Canada \\ ${ }^{4}$ University of California - Irvine, Department of Ecology and Evolutionary Biology, Irvine, California 92697, USA \\ ${ }^{5}$ Present address: School of Aquatic and Fishery Sciences, Box 355020, University of Washington, Seattle, \\ Washington 98195, USA
}

\begin{abstract}
Each year, millions of seabirds migrate to the North Water Polynya, northern Baffin Bay, to feed in its productive waters during the 6 months that the polynya is free of ice. We evaluated seasonal shifts in diets of 3 species using the North Water: dovekie Alle alle, thick-billed murre Uria lomvia, and black-legged kittiwake Rissa tridactyla. Diets were assessed through a combination of stable isotope analysis of muscle tissue, fatty acid analysis of subcutaneous fat, and stomach content analysis. Dovekies had the lowest $\delta^{15} \mathrm{~N}$ values and hence lowest trophic level in spring and summer, corresponding to their consumption of herbivorous copepods. In fall, their $\delta^{15} \mathrm{~N}$ values increased as they switched to feeding at a higher trophic level on primary carnivores such as amphipods and fish. Throughout the study period, kittiwakes and murres had stomach contents and stable isotope values similar to dovekies in fall. Fatty acid signatures of black-legged kittiwakes and dovekies feeding in fall were similar, likely due to the reliance of both species on the pteropod Limacina limacina. Our study highlights the seasonal nature of prey availability and seabird diets in the polynya, as well as the utility of simultaneously using conventional stomach content analysis and stable isotope and fatty acid analyses to infer dietary patterns in marine food webs.
\end{abstract}

KEY WORDS: Diet assessment $\cdot$ Stomach contents $\cdot$ Stable isotope analysis $\cdot$ Fatty acid signatures Seabird $\cdot$ Arctic $\cdot$ Polynya

Resale or republication not permitted without written consent of the publisher

\section{INTRODUCTION}

The North Water is the largest and most productive Arctic polynya or seasonally ice-free body of water (Fig. 1). Each year, millions of seabirds migrate to the polynya to feed in its waters and to breed along its shores (Karnovsky \& Hunt 2002, Egevang et al. 2003). Understanding how different species of seabirds utilize the polynya provides insight into seasonal changes in biological processes in the polynya. An estimated 33 million pairs of dovekies Alle alle (hereafter 'dovekies') breed along the western coast of Greenland adjacent to the North Water (Egevang et al. 2003). These small subsurface feeders dive up to $35 \mathrm{~m}$
(Falk et al. 2000). Thick-billed murres Uria lomvia (hereafter 'murres'; estimated population 350000 pairs; Falk \& Kampp 1997) are large subsurface divers that regularly dive to depths over $70 \mathrm{~m}$ (Falk et al. 2002). Black-legged kittiwakes Rissa tridactyla (hereafter 'kittiwakes') are surface feeders that also make shallow dives (estimated population 30000 pairs; McLaren 1982). These 3 species represent the vast majority of seabirds in the polynya's food web and encompass a diversity of feeding guilds.

In the Arctic, food webs are characterized by the rapid transfer of energy from inorganic substrates to phytoplankton, zooplankton, and ultimately to upper trophic level predators. In spring, as areas become ice free, 


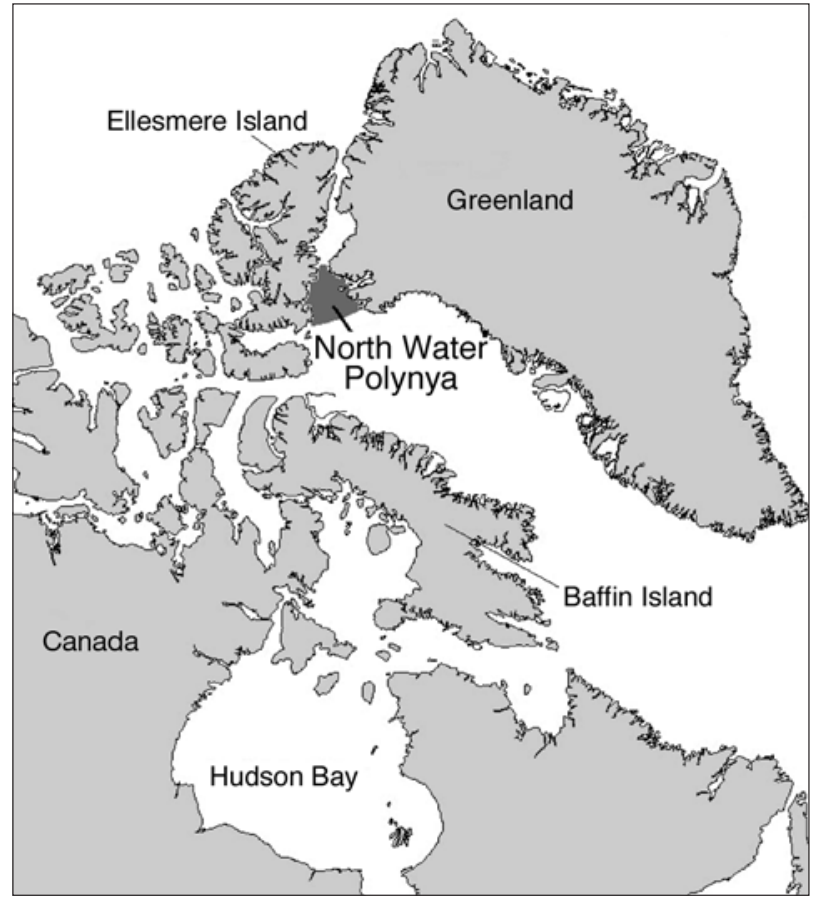

Fig. 1. The North Water Polynya, located between Ellesmere Island, Canada, and Western Greenland

sunlight promotes the proliferation of phytoplankton, which is subsequently grazed by herbivorous zooplankton. These zooplankton are, in turn, preyed upon by carnivorous zooplankton, fish, birds, seals, and whales (e.g. Karnovsky \& Hunt 2002). Once the spring phytoplankton bloom has begun, energy is transferred to multiple consumers through a variety of pathways. These pathways of energy flux change as the season of open water progresses. By using 3 species of seabirds with different foraging ecologies, our objectives were to gain insight into the consequences to upper trophic levels of the polynya's seasonal food web dynamics.

Until recently, understanding diets of upper trophic level predators was solely dependent on conventional analysis of stomach contents, which reveals the prey that an individual has eaten for its last meal; however, this may not reflect the identity of commonly taken prey. More recently, 2 biochemically based techniques have been applied to assess diets or trophic positions of organisms. The stable isotope approach has been useful in modeling trophic-level interactions among marine organisms (e.g. Hobson \& Welch 1992), and the analysis of fatty acid signatures in marine food webs has provided quantitative information on specific dietary components (Iverson et al. 2004). Both techniques rely on the assumption that elemental or molecular compositions of tissues in predators reflect those in prey consumed.
Stable isotope analysis typically has used the measurement of ratios of naturally occurring stable isotopes of carbon and nitrogen in tissues. Stable carbon isotope ratios $\left({ }^{13} \mathrm{C} /{ }^{12} \mathrm{C}\right)$ change slightly across trophic levels (e.g. Hobson \& Welch 1992) and so can be used to trace sources of primary productivity. Carbon isotopic enrichment also occurs in benthic versus pelagic systems and thus can provide spatial or geographic information on feeding (Hobson et al. 1995). Stable nitrogen isotope ratios $\left({ }^{15} \mathrm{~N} /{ }^{14} \mathrm{~N}\right)$ show step-wise enrichment with trophic level and are therefore used primarily as indicators of trophic position (Michener \& Schell 1994).

Fatty acids are the largest constituent of most lipids; in the marine environment, they are characterized by a unique and diverse array of structures that occur in different relative abundance among organisms. Because fatty acids are incorporated from prey into predator fat stores either without modification or in a predictable manner, fatty acids can be analyzed and used to compare differences in diets among groups of predators. In captive feeding trials on seabirds, shifts in prey were detected in fatty acid signatures within $5 \mathrm{~d}$ (Käkelä et al. 2005). The evaluation of fatty acid signatures has been useful in examining interannual differences in prey usage (e.g. Walton \& Pomeroy 2003), differences in foraging patterns of different populations (Smith et al. 1996, Iverson et al. 1997), and ecological niches (e.g. Auel et al. 2002), as well as inferring major contributors to diets (e.g. Hooker et al. 2001).

Only a few studies have combined both methods to examine foraging and trophic interactions (e.g. Smith et al. 1996, Hooker et al. 2001, Dahl et al. 2003). Each technique has its strengths and weaknesses; however, when combined, many of the limitations of each technique can be overcome. In the present study, we examined seasonal differences in stable isotope values, fatty acid composition, and stomach contents of 3 species of seabirds (dovekies, murres, and kittiwakes) to understand the seasonal dynamics of energy flow in the North Water Polynya.

\section{MATERIALS AND METHODS}

Dovekies, kittiwakes, and murres were collected by shotgun at sea throughout the polynya for a study of contaminants in the Arctic (Fisk et al. 2001). Bird collections were made in May to July 1998 and August to September 1999. Birds collected on 10 separate days in May 1998 were considered spring birds. Those collected on 17 different days in June and July 1998 were summer birds, and those collected during 16 days in August and September 1999 were fall birds. Due to the timing of the research cruises, more than a full year 
passed between summer and fall collections. In total, 410 birds were collected in this study. Sample sizes for each type of analysis varied (Table 1). All 3 analyses (stable isotope analysis of muscle, fatty acid signatures of subcutaneous lipids, and stomach contents) were done on 65 birds.

Stable isotope analysis. Immediately after collection, small subsamples $(\sim 1 \mathrm{~g})$ of muscle were collected from birds and frozen. Methods followed those described by Hobson et al. (2002a).

Fatty acid signature analysis. Subcutaneous fat samples were taken after birds were collected and frozen at $-20^{\circ} \mathrm{C}$. Sample analysis followed procedures used by Iverson et al. (2004). Because wax esters are one of the most common forms of lipid classes in certain marine organisms, alcohols and dimethyl acetals were converted to free fatty acids and then recombined with fatty acid methyl esters to accurately account for all fatty acids digested or deposited (see Budge \& Iverson 2003).

Stomach content analysis. After collection, stomachs and proventriculi were removed, weighed, and preserved in ethanol and/or kept frozen. In the laboratory, stomach contents were examined under fluorescent light microscopes to retrieve small otoliths and rinsed in dark-bottomed pans. Because there are 2 sagittal otoliths in fish, the number of otoliths was divided by 2 so that fish numbers in the diets were not overestimated. Crustaceans were identified under a dissection microscope and enumerated. Most amphipods were found broken in half. All heads and all telsons were counted within each diet sample. The greater number of either heads or telsons was taken as the number of amphipods within a sample.

Statistical analyses. To understand how birds varied in trophic level, depending on pelagic versus benthic feeding, or ice algae- versus pelagic-phytoplankton based diets, we used 1-way analysis of variance (ANOVA) on untransformed stable isotope values. To discern overall similarities and differences in $\delta^{15} \mathrm{~N}$ and $\delta^{13} \mathrm{C}$ values among birds feeding in different seasons, we used multivariate ANOVA (MANOVA).

Principal component analysis (PCA) in conjunction with ANOVA was used to assess possible differences in fatty acid composition among the 3 seabirds in different seasons. Fatty acids that made up at least $5 \%$ of the fat composition in any predator species were retained, and those with less than that value were deleted along with any problematic fatty acids (i.e. those that were biosynthesized or difficult to measure).

To control for unequal sample sizes among predators and to thus give equal importance to each predator in the statistical outcome, the PCA was weighted by the sample size for each species. To test for significant differences in fatty acid composition among predator species, we used two 1-way ANOVAs. In the first, we tested for differences among the $\mathrm{PC} 1$ scores of individuals representing the 8 species/season groups, and in the second we compared PC2 scores among those individuals. We considered differences between 2 species/seasons to be significant if either or both of the PC1 or PC2 scores differed significantly between them.

Results from stomach content analyses were treated as percent occurrence and percent total. Percent occurrence of a taxon was the percentage of birds within a group that had that particular taxon in their stomachs. Percent total refers to the percent that each taxon contributed to the total number of prey found within all stomach samples of birds of a given species during a season.

\section{RESULTS}

\section{Stable isotope analysis}

Seasonal changes in trophic level were examined using $\delta^{15} \mathrm{~N}$ values. Seasonal changes in muscle $\delta^{15} \mathrm{~N}$ values were most pronounced in dovekies (ANOVA, $F_{2,144}=227.7, \mathrm{p}<0.01$ ) (Fig. 2). Fall dovekie muscle

Table 1. Alle alle, Uria lomvia, and Rissa tridactyla. Sample sizes of birds used in each analysis during 3 seasons

\begin{tabular}{|c|c|c|c|c|}
\hline Season & Species & $\begin{array}{c}\text { Stomach content } \\
\text { analysis }\end{array}$ & $\begin{array}{l}\text { Stable isotope } \\
\text { analysis }\end{array}$ & $\begin{array}{c}\text { Fatty acid signature } \\
\text { analysis }\end{array}$ \\
\hline Spring & $\begin{array}{c}\text { Dovekie } \\
\text { Black-legged kittiwake } \\
\text { Thick-billed murre }\end{array}$ & $\begin{array}{l}33 \\
12 \\
17\end{array}$ & $\begin{array}{l}42 \\
10 \\
20\end{array}$ & $\begin{array}{l}10 \\
10 \\
10\end{array}$ \\
\hline Summer & $\begin{array}{c}\text { Dovekie } \\
\text { Black-legged kittiwake } \\
\text { Thick-billed murre }\end{array}$ & $\begin{array}{l}79 \\
23 \\
60\end{array}$ & $\begin{array}{l}80 \\
16 \\
42\end{array}$ & $\begin{array}{c}20 \\
12 \\
0\end{array}$ \\
\hline Fall & $\begin{array}{c}\text { Dovekie } \\
\text { Black-legged kittiwake } \\
\text { Thick-billed murre }\end{array}$ & $\begin{array}{l}45 \\
24 \\
14\end{array}$ & $\begin{array}{l}25 \\
27 \\
11\end{array}$ & $\begin{array}{c}18 \\
14 \\
9\end{array}$ \\
\hline Total & & 307 & 273 & 103 \\
\hline
\end{tabular}


tissue was enriched compared to spring and summer values. Conversely, muscle $\delta^{15} \mathrm{~N}$ values for kittiwakes were highest in spring and summer versus fall (Fig. 2) $\left(F_{2,50}=8.14, \mathrm{p}<\right.$ 0.001). Like the kittiwakes, peak $\delta^{15} \mathrm{~N}$ muscle values in murres occurred in summer and declined in fall to values similar to those obtained in spring $\left(F_{2,70}=13.4, \mathrm{p}<0.001\right)$.

To examine the extent to which diets were based on different sources of phytoplankton, we examined tissue $\delta^{13} \mathrm{C}$ values. Unlike dovekie $\delta^{15} \mathrm{~N}$ values, $\delta^{13} \mathrm{C}$ values did not differ significantly over the seasons ( $p>0.05$ ). $\delta^{13} \mathrm{C}$ ratios varied within both murres and kittiwakes (ANOVA, $F_{2,70}=20.8, \mathrm{p}<0.001$; $F_{2,50}=7.6, \mathrm{p}=0.001$, respectively) albeit in opposite directions. Lowest $\delta^{13} \mathrm{C}$ values for kittiwakes were found in the fall, when $\delta^{13} \mathrm{C}$ values were highest for murres.

\section{Fatty acid signature analysis}

In the PCA comparing fatty acid composition among seabirds feeding in different seasons, the first 2 PC axes explained 56.6\% of the variance in prey species intake by the 8 predator species/seasons groups. The 8 species/seasons sorted into 3 distinct groups on the basis of these loadings (Sidak tests, all $\mathrm{p}<0.0001$ ) (Fig. 3). One group was represented by spring and summer dovekies, another by fall dovekies and fall kittiwakes, and the third by spring and summer murres and summer kittiwakes. Spring kittiwake fatty acid composition was similar to that for summer kittiwakes, but differed from that of spring and fall murres.

\section{Stomach content analysis}

Analysis of stomach contents revealed that birds foraging in the North Water had varied diets throughout the seasons (see Figs. 4 \& 5). However, in spring and summer, 53 and $68 \%$, respectively, of dovekies had Calanus spp. copepods in their stomachs (Fig. 4), which made up almost $100 \%$ of their diets (Fig. 5). Dovekies frequently consumed Themisto libellula in spring (31\%) and summer (51\%, Fig. 4) but in low numbers (Fig. 5). Representation in dovekie stomach contents of $T$. libellula increased as the seasons progressed to a maximum of $60 \%$ occurrence in fall (Fig. 4). Only dovekies contained the epontic amphipod Apherusa glacialis, which they

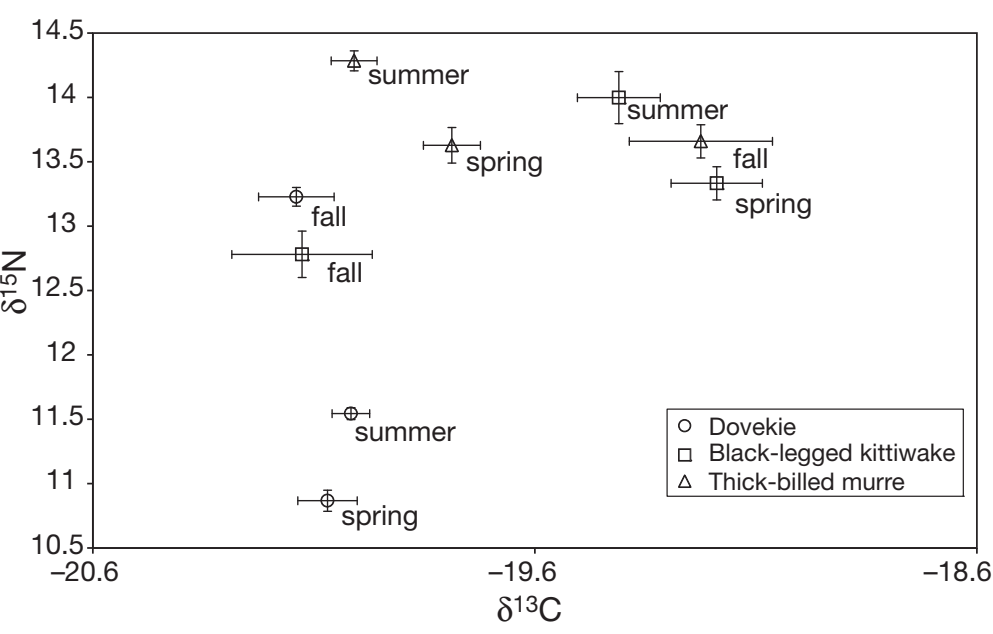

Fig. 2. Alle alle, Rissa tridactyla, and Uria lomvia. Stable carbon and nitrogen isotope values (mean $\pm \mathrm{SE}$ ) of lipid-extracted muscle tissues of birds feeding during different seasons in the North Water

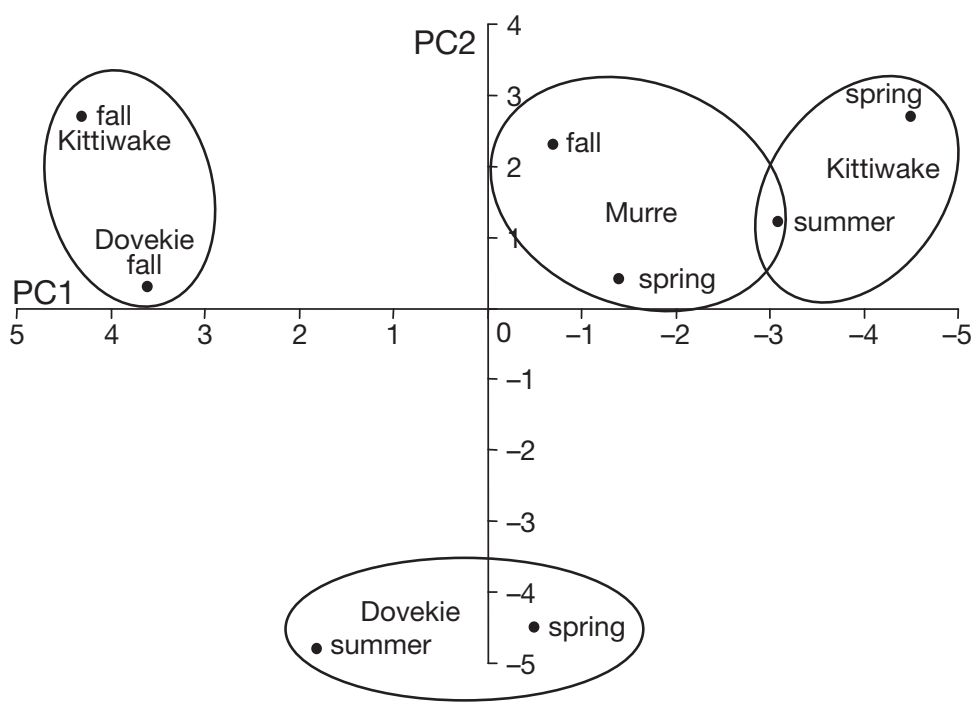

Fig. 3. Alle alle, Rissa tridactyla, and Uria lomvia. Results of a PCA to compare fatty acid composition among 8 species/season groups of birds foraging in the North Water. The percent variance explained by PC1 and PC2 was $56 \%$. Fatty acid composition of species groups enclosed in the same circle were not significantly different (Sidak multiple comparisons test, all $\mathrm{p}>0.05$ )

consumed throughout the seasons. In fall, this prey species constituted $62 \%$ of dovekie diet by number (Fig. 5), although this result was driven by the influence of a single bird that had 261 individuals of this species in its stomach. When this bird was not included, A. glacialis and Calanus hyperboreus made up 24 and $25 \%$, respectively, of all prey items consumed in fall. Kittiwake stomach contents consisted primarily of Arctic cod Boreogadus saida and T. libellula (Figs. 4 \& 5). In fall, 13 of 25 kittiwake stomachs 
contained the pteropod Limacina limacina. Murres, with their reliance on B. saida and T. libellula, had stomach contents similar to those of kittiwakes (Figs. 4 \& 5). Murres apparently did not consume L. limacina; however, they often had copepods in their stomachs. In spring, Metridia longa made up $26 \%$ of the total number of prey found in murre stomachs. These small copepods likely occurred in the stomachs of B. saida consumed by murres. $M$. longa was found in the stomachs of a few fish recently consumed by murres (N. J. Karnovsky pers. obs.).
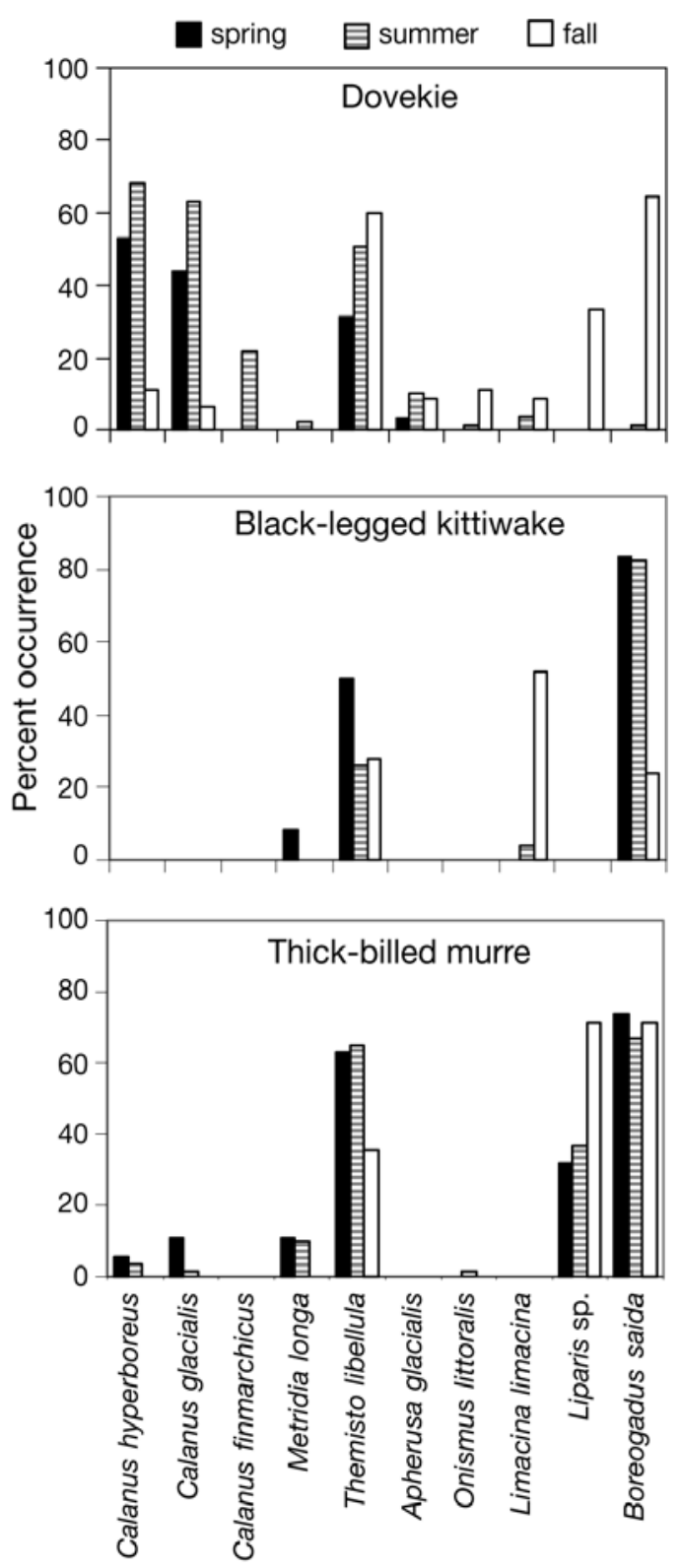

Fig. 4. Alle alle, Rissa tridactyla, and Uria lomvia. Percent (\%) frequency of occurrence that birds feeding in different seasons consumed different prey taxa

\section{DISCUSSION}

Seabird feeding habits in the North Water Polynya were highly seasonal, a phenomenon revealed by all 3 analytical techniques. Stable isotope analysis provided insight into seasonal trophic level changes within species. Fatty acid signatures provided evidence that diets differed among seasons. Stomach content analysis provided corroborating evidence for predictions about directions and extent of dietary changes inferred from fatty acid and stable isotope analyses. In addition, it revealed the unexpected use of Limacina limacina and allowed us to understand how dovekies and kittiwakes could have similar fatty acid signatures. As such, the combined approach resulted in greater insight into the feeding dynamics of seabirds in this system than could have been achieved through any one approach alone.
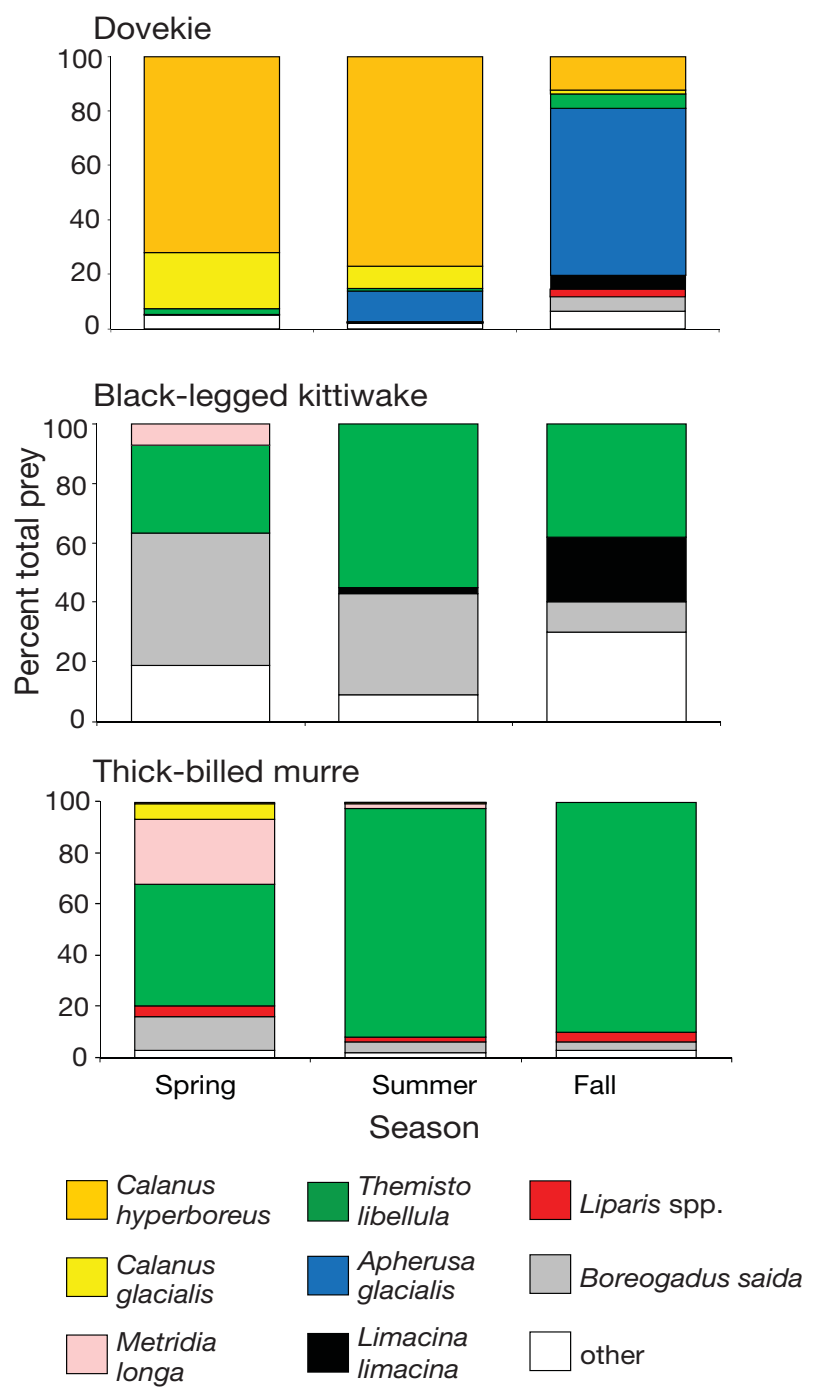

Fig. 5. Alle alle, Rissa tridactyla, and Uria lomvia. Percent (\%) total number of prey taxa eaten by birds in different seasons 


\section{Seasonal changes in the North Water Polynya}

Our data were collected over a 2 yr period and comprised a seasonal cycle from spring through fall. We realize that inter-annual differences in the timing of the physical processes responsible for the formation of the polynya and the ensuing biological properties that occur may have influenced our results. However, because of our large sample sizes throughout the seasons and the regular occurrence of the polynya (Barber et al. 2001), we believe that the patterns presented here are representative of the regular seasonal patterns at work in the North Water. Regular seasonal changes have been described in the patterns of the development of the water-column structure (Bâcle et al. 2002), and the timing of the onset of and development of primary production (e.g. Klein et al. 2002). In early spring, large-sized adult copepods dominate the zooplankton community (Ringuette et al. 2002) and are responsible for high levels of grazing (Saunders et al. 2003). Estimates of seasonal changes in other zooplankton and fish are not available, although Themisto libellula and Boreogadus saida were presumably available throughout the seasons.

\section{Dovekie}

Of the 3 seabird species examined, dovekies showed the most dramatic seasonal changes in diet. Stable isotope analysis showed that dovekies went from feeding at the lowest trophic level in the spring to one of the highest in the fall. Stomach content analysis showed that in spring, dovekies mainly consumed Calanus hyperboreus, which are herbivorous copepods. Isotopic analysis revealed that dovekies fed at a slightly higher trophic level in summer, which was likely a reflection of the increasing frequency with which dovekies consumed the omnivorous copepod Calanus glacialis. In the fall, stomach contents of dovekies were made up of a mixture of Themisto libellula and Boreogadus saida, a finding confirmed by their high $\delta^{15} \mathrm{~N}$ ratios during that season. Stomach content analysis revealed that dovekies were the only study species to consume the epontic amphipod Apherusa glacialis. Fall dovekies grouped with fall kittiwakes in the PCA based on fatty acid data, indicating that they had a similar diet, which was confirmed by the stomach content analysis.

\section{Black-legged kittiwake}

Based on stable isotope analyses, the trophic level of kittiwakes feeding in summer and spring remained similar. However, kittiwake trophic level declined in fall. Kittiwakes feeding in spring and summer had similar fatty acid signatures that differed from birds feeding in fall, and they had a fatty acid composition similar to dovekies feeding in fall. Examination of diets of kittiwakes shows that in fall, many birds consumed the pteropod Limacina limacina in large numbers. Interestingly, dovekies in fall also consumed L. limacina, although at lower frequencies and quantities. Perhaps the contribution of fatty acids from this pteropod is responsible for the similarities in fatty acid composition between dovekies and kittiwakes feeding in fall. L. limacina is a herbivore and is likely to have reduced the $\delta^{15} \mathrm{~N}$ values of kittiwakes in fall.

\section{Thick-billed murre}

Of the 3 seabird species, murres showed the least variation in trophic level among seasons. Despite a relatively constant diet of Boreogadus saida and Themisto libellula, there were differences in fatty acid signatures among seasons. This could be a reflection of the changes in the diets of prey or even changes in phytoplankton input to the prey of B. saida and T. libellula. For example, if copepods consumed by fish predators had ingested diatoms in spring and dinoflagellates in fall, these changes could be reflected in the fatty acid signatures of murres. Fatty acid signatures of murres grouped with kittiwakes in summer. Analysis of stomach contents revealed that during summer, murres had a catholic (fish-eating) diet, similar to that of kittiwakes.

\section{Stable isotope analysis}

We found that $\delta^{13} \mathrm{C}$ and $\delta^{15} \mathrm{~N}$ values of seabird tissues varied among species and seasons. In the North Water, Hobson et al. (2002a) isotopically modeled trophic levels for a variety of upper trophic level predators based on an average throughout the season. They found that murres fed at the highest trophic level of the 3 seabirds examined here and dovekies at the lowest. Our results indicate that the trophic status of each species changes on a seasonal basis. In fall, dovekies changed their feeding habits and acquired a slightly higher trophic status than kittiwakes, whose trophic level declined at that time. In dovekies, this shift in trophic level was driven by the switch to carnivorous amphipods and fish in fall, and in kittiwakes, by their consumption of Limacina limacina.

In comparison to our $\delta^{15} \mathrm{~N}$ results, $\delta^{13} \mathrm{C}$ values showed less seasonal variation for all species of birds. Despite the fact that $\delta^{13} \mathrm{C}$ values varied significantly in kittiwakes and murres, this does not imply deviations from 
pelagic feeding habits. Some of the higher $\delta^{13} \mathrm{C}$ values (e.g. in spring feeding kittiwakes) could reflect inputs from an ice-algae based food web. These differences are not likely to be reflective of a pelagic- versus benthic-derived diet, because kittiwakes and murres fed mainly in the pelagic environment. Based on stomach analyses, none of the birds sampled consumed benthic taxa, so this seasonal trend may be a reflection of a transition from prey that had used ice-algae, to prey that had used pelagic phytoplankton (Hobson et al. 1995). In May, ice was plentiful in the study area, and birds were often seen feeding along ice edges and in leads of pack ice (N. J. Karnovsky pers obs.).

While we attribute shifts in seabird trophic level to seasonal changes in their diets, some variability in trophic level may be attributed to spatial and interannual differences. In a concurrent study of spatial and inter-annual differences between seabirds breeding on opposite sides of the polynya, Hobson et al. (2002b) found some variation between colonies. Because we collected birds throughout the polynya, and did not examine the effect of location on isotope values or diet per se, spatial differences among seabirds were averaged in our results. Seasonal trends in trophic level were largely driven by seasonal changes in food availability in conjunction with constraints of foraging strategies of seabirds.

\section{Fatty acid analysis}

Results of fatty acid analysis indicated seasonal shifts in prey, although specific prey types could not be identified. However, we could make qualitative predictions on the basis of known fatty acid properties of certain prey. Sargent $(1976,1978)$ found that after they consume phytoplankton, calanoid copepods store lipids as wax esters containing fatty acids, and they also biosynthesize fatty acids and alcohols with 20 and 22 carbon atoms. These monounsaturated fatty alcohols can be found in copepod predators (Roby et al. 1986, Sargent \& Henderson 1986, Falk-Petersen et al. 1987). Calanus spp. copepods were the primary prey of dovekies in spring and summer, and since these copepods were readily available during those months, they were likely preyed on heavily by fish and predatory amphipods such as Themisto libellula. In Svalbard, Arctic cod Boreogadus saida, the primary prey of kittiwake and murres, were found to have high concentrations of these calanoid fatty acids, which were likely derived from consumption of calanoid copepods and T. libellula, which also consume calanoid copepods (Dahl et al. 2003). We found that levels of 20:1(n-9) and 22:1(n-11), which are biosynthesized by calanoid copepods in large amounts (Sargent \& Henderson 1986), had highest average percentages in all 3 species of birds in spring and summer. Levels of 20:1(n-9) were highest in dovekies in spring. It is not unexpected that all 3 species would have high levels of these fatty alcohols. Seasonal changes in the levels of these 2 long chain fatty alcohols may reflect the infusion of energy into the marine food web derived from herbivorous calanoid copepods that occurred in spring and summer.

While our results appear to indicate shifts in prey usage, some of the seasonal changes in fatty acid composition may be due, in part, to shifts in the base of the food web from diatoms to dinoflagellates (Klein et al. 2002). Seasonal changes in diets of copepods in the wild have been documented through fatty acid analysis (Sargent \& Falk-Petersen 1988). In captive feeding experiments, Graeve et al. (1994) found that copepods fed diets of diatoms increased in their level of 16:1(n-7), and when fed dinoflagellates, they increased in 18:4(n-3). Interestingly, levels of 16:1(n-7) in all 3 species of birds consistently increased as the seasons progressed. This pattern is counter to what we expected, since diatom blooms were prevalent in the spring and summer and small-sized cells were more common in fall (Klein et al. 2002). Levels of 18:4(n-3) varied and showed no consistent trend. It is unknown how well examination of these single fatty acid markers in upper trophic predators can indicate shifts from diatoms to dinoflagellates at the base of the food web.

\section{Stomach content analysis}

Stomach content analysis has the advantage that actual taxa of prey can be identified and quantities of prey estimated. However, there are drawbacks to the singular application of this technique. Most significantly, birds often have empty stomachs. In the present study, 103 of the 410 birds collected had empty stomachs.

Other difficulties include degradation of material in stomachs, which can hamper identification and enumeration of prey. Our study had the advantage of large sample sizes and most prey could be identified to species and certainly to genus. Small otoliths are digested fairly rapidly (Van Heezik \& Seddon 1989). We were confident that otolith presence was not underestimated because we recovered many pairs of sagittal otoliths in their skull cases, and many small sagittal otoliths were found in conjunction with their smaller and more fragile counterparts (lapilli and asterici).

Dovekies showed clear seasonal shifts in their diets from a spring and summer copepod diet to one based on Arctic cod and Themisto libellula, as was described by Bradstreet (1982). This trend was confirmed with stable isotope and fatty acid signature analyses. Kitti- 
wakes are known to consume primarily Arctic cod (Welch \& Crawford 1993) and to a lesser extent zooplankton such as Parathemisto libellula (Mehlum \& Gabrielsen 1993). Pteropods were found in the stomachs of 4 kittiwakes feeding in fall in Hornsund Fjord, Spitsbergen (Lydersen et al. 1989). Our study confirms the importance of pteropods for kittiwakes feeding in fall. Our findings of diets of murres are consistent with other studies (e.g. Bradstreet \& Brown 1985); however, it was not known that murres took Liparis sp. of lumpfish to the extent that we found.

\section{SUMMARY}

Major shifts in diets that were predicted by stable isotope or fatty acid analyses were generally validated by stomach content analysis. By combining techniques that integrate diets over days and weeks, we gained a more complete understanding of how diets shifted over time and the trophic linkages among organisms.

Our examination of changes in diets over the seasons provides a very different picture of seabird foraging habits in the High Arctic than was previously known. Most previous knowledge of seabird diets in the polynya and surrounding areas has been collected only during summer and reflects mainly what adult birds feed their chicks. We have expanded our understanding of these parameters to include the spring season, prior to egg-laying, through fall, after chicks have fledged. Our results show that each of the 3 seabird species changed their feeding habits from spring to fall. Shifts in diets reflect changes as the spring bloom is initiated and energy begins to flow through herbivorous zooplankton to upper trophic level predators. The polynya opens in April and closes again in late September. During that time, the pathways of energy flux to seabirds varied tremendously. If we had not chosen to examine seasonal variation in seabird diets, we would not have identified many of the key links between zooplankton secondary production and fish and seabirds. Our study highlights the intensely seasonal nature of the polynya's food web and demonstrates the power of combining approaches to assess predator diets.

Acknowledgements. We are grateful to the crew, officers, and captains of the Canadian Coast Guard Service (CCGS) 'Louis St. Laurent' and 'Pierre Radisson' for their assistance. Thanks to the Hunters and Trappers Associations of Grise Fiord, Nunavut, and Qaanaaq, Greenland, for permission for the project to collect birds in their regions. Collections were made under a permit from the Canadian Wildlife Service. P. Akeeagok, D. Andriashek, W. Calvert, J. Carlson, A. Fisk, M. Holst, N. Lunn, I. Stirling, and J. Zamon provided assistance in the field. We also thank M. Fortier and C. Michel for help with logistics. Thanks to chief scientists L. Fortier,
M. Gosselin, and B. Hargrave for their support throughout the project. S. Lang processed the lipid samples. P. Healy performed stable isotope sample preparation. Stable isotope measurements were conducted at the Department of Soil Science, University of Saskatchewan. This work was supported by National Science Foundation Office of Polar Programs grant number OPP 9725071. This paper is a contribution to the International North Water Polynya Project initiated under the Arctic Ocean Sciences Board.

\section{LITERATURE CITED}

Auel H, Harjes M, da Rocha R, Stubing D, Hagen W (2002) Lipid biomarkers indicate different ecological niches and trophic relationships of the Arctic hyperiid amphipods Themisto abyssorum and T. libellula. Polar Biol 25:374-383

Bâcle J, Carmack EC, Ingram RG (2002) Water column structure and circulation under the North Water during spring transition: April-July 1998. Deep-Sea Res 49:4907-4925

Barber DG, Hanesiak JM, Chan W, Piwowar J (2001) Sea-ice and meteorological conditions in Northern Baffin Bay and the North Water Polynya between 1979 and 1996. AtmosOcean 39:343-359

Bradstreet MSW (1982) Pelagic feeding ecology of dovekies Alle alle in Lancaster Sound and western Baffin Bay. Arctic 35:126-140

Bradstreet MSW, Brown RGB (1985) Feeding ecology of the Atlantic Alcidae. In: Nettleship DN, Birkhead TR (eds) The Atlantic Alcidae. Academic Press, London, p 262-318

Budge SM, Iverson SJ (2003) Quantitative analysis of fatty acid precursors in marine samples: direct conversion of wax ester alcohols and dimethylacetals to FAMEs. J Lipid Res 44:1802-1807

Dahl TM, Falk-Petersen S, Gabrielsen GW, Sargent JR, Hop H, Millar RM (2003) Lipids and stable isotopes in common eider, black-legged kittiwake and northern fulmar: a trophic study from an Arctic fjord. Mar Ecol Prog Ser 256: $257-269$

Egevang E, Boertmann D, Mosbech A, Tamstorf MP (2003) Estimating colony area and population size of little auks Alle alle at Northumberland Island using aerial images. Polar Biol 26:8-13

Falk K, Kampp K (1997) A manual for monitoring thick-billed murre populations in Greenland. Tech Rep No. 8. Greenland Institute of Natural Resources, Nuuk

Falk K, Pedersen CE, Kampp K (2000) Measurements of diving depths in dovekies (Alle alle). Auk 117:522-525

Falk K, Benvenuti S, Dall'Antonia L, Gilchrist G, Kampp K (2002) Foraging behavior of thick-billed murres breeding in different sectors of the North Water polynya: an intercolony comparison. Mar Ecol Prog Ser 231:293-302

Falk-Petersen S, Sargent JR, Tande KS (1987) Lipid composition of zooplankton in relation to the sub-Arctic food web. Polar Biol 8:115-120

Fisk AT, Moisey J, Hobson KA, Karnovsky NJ, Norstrom RJ (2001) Chlordane components and metabolites in seven species of Arctic seabirds from the Northwater Polynya: relationships with stable isotopes of nitrogen and enantiomeric fractions of chiral components. Environ Pollut 113:225-238

Graeve M, Kattner G, Hagen W (1994) Diet-induced changes in the fatty acid composition of Arctic herbivorous copepods: experimental evidence of trophic markers. J Exp Mar Biol Ecol 182:97-110

Hobson KA, Welch HE (1992) Determination of trophic relationships within a High Arctic marine food web using 
stable-isotope analysis. Mar Ecol Prog Ser 84:9-18

Hobson KA, Ambrose WG Jr, Renaud PE (1995) Sources of primary production, benthic-pelagic coupling, and trophic relationships within the Northeast Water Polynya: insights from $\delta^{13} \mathrm{C}$ and $\delta^{15} \mathrm{~N}$ analysis. Mar Ecol Prog Ser 128:1-10

Hobson KA, Fisk A, Karnovsky N, Holst M, Gagnon JM, Fortier M (2002a) A stable isotope $\left(\delta^{13} \mathrm{C}, \delta^{15} \mathrm{~N}\right)$ model for the North Water food web: implications for evaluating trophodynamics and the flow of energy and contaminants. Deep-Sea Res 49:5131-5150

Hobson KA, Gilchrist G, Falk K (2002b) Isotopic investigations of seabirds of the North Water polynya: contrasting trophic relationships between the eastern and western sectors. Condor 104:1-11

Hooker SK, Iverson SJ, Ostrom P, Smith SC (2001) Diet of northern bottlenose whales inferred from fatty-acid and stable-isotope analyses of biopsy samples. Can J Zool 79: $1442-1454$

Iverson SJ, Frost KJ, Lowry LF (1997) Fatty acid signatures reveal fine scale structure of foraging distribution of harbor seals and their prey in Prince William Sound, Alaska. Mar Ecol Prog Ser 151:255-271

Iverson SJ, Field C, Bowen WD, Blanchard W (2004) Quantitative fatty acid signature analysis: a new method of estimating predator diets. Ecol Monogr 74:211-235

Käkelä R, Käkelä A, Rahle S, Becker PH, Kelly A, Furness RW (2005) Fatty acid signatures in captive herring gulls as indicators of demersal or pelagic fish diet. Mar Ecol Prog Ser 293:191-200

Karnovsky NJ, Hunt GL (2002) Estimation of carbon flux to dovekies (Alle alle) in the North Water. Deep-Sea Res 49: $5117-5130$

Klein B, Leblanc B, Mei ZP, Béret R and others (2002) Phytoplankton biomass, production and potential export in the North Water. Deep-Sea Res 49:4983-5002

Lydersen C, Gjertz I, Węsławski JM (1989) Stomach contents of autumn-feeding marine vertebrates from Hornsund, Svalbard. Polar Rec 25:107-114

McLaren PL (1982) Spring migration and habitat use by seabirds in eastern Lancaster Sound and western Baffin Bay. Arctic 35:88-111

Mehlum F, Gabrielsen GW (1993) The diet of high-artic

Editorial responsibility: Howard Browman,

Storebø, Norway seabirds in coastal and ice-covered, pelagic areas near the Svalbard archipelago. Polar Res 12:1-20

Michener RH, Schell DM (1994) Stable isotope ratios as tracers in marine and aquatic food webs. In: Lajtha $\mathrm{K}$, Michener RH (eds) Stable isotopes in ecology and environmental science. Blackwell, Oxford, p 138-157

Ringuette M, Fortier L, Fortier M, Runge JA, Bélanger S, Larouche P, Węsławski JM, Kwasniewski S (2002) Advanced recruitment and accelerated population development in Arctic calanoid copepods of the North Water. Deep-Sea Res 49:5081-5099

Roby DD, Place AR, Ricklefs RE (1986) Assimilation and deposition of wax esters in planktivorous seabirds. J Exp Zool 238:29-42

Sargent JR (1976) The structure, metabolism and function of lipids in marine organisms. In: Malins DC, Sargent JR (eds) Biochemical and biophysical perspectives in marine biology. Academic Press, London, p 149-212

Sargent JR (1978) Marine wax esters. Sci Prog 65:437-458

Sargent JR, Falk-Petersen S (1988) The lipid biochemistry of calanoid copepods. Hydrobiologia 167/168:101-114

Sargent JR, Henderson RJ (1986) Lipids. In: Corner EDS, O'Hara SCM (eds) The biological chemistry of marine copepods. Clarendon Press, Oxford, p 59-108

Saunders PA, Deibel D, Stevens CJ, Rivkin RB, Lee SH, Klein B (2003) Copepod herbivory rate in a large arctic polynya and its relationship to seasonal and spatial variation in copepod and phytoplankton biomass. Mar Ecol Prog Ser 261:183-199

Smith RJ, Hobson KA, Koopman HN, Lavigne DM (1996) Distinguishing between populations of fresh- and salt-water harbour seals (Phoca vitulina) using stable-isotope ratios and fatty acid profiles. Can J Fish Aquat Sci 53:272-279

Van Heezik YM, Seddon P (1989) Stomach sampling in the Yellow-eyed penguin: erosion of otoliths and squid beaks. J Field Ornithol 60:451-458

Walton M, Pomeroy P (2003) Use of blubber fatty acid profiles to detect inter-annual variations in the diets of grey seals Halichoerus grypus. Mar Ecol Prog Ser 248:257-266

Welch HE, Crawford RE (1993) Occurrence of Arctic cod (Boreogadus saida) schools and their vulnerability to predation in the Canadian High Arctic. Arctic 46:331-339

Submitted: May 22, 2006; Accepted: October 22, 2007

Proofs received from author(s): March 20, 2008 